9-3-2010

\title{
The Scientific Model of Jurisprudence
}

Dan Priel

Osgoode Hall Law School of York University, dpriel@osgoode.yorku.ca

Follow this and additional works at: http://digitalcommons.osgoode.yorku.ca/all_papers

\section{Repository Citation}

Priel, Dan, "The Scientific Model of Jurisprudence" (2010). All Papers. Paper 256.

http://digitalcommons.osgoode.yorku.ca/all_papers/256 


\section{The Scientific Model of Jurisprudence}

Dan Priel*

Shortly after John Austin published The Province of Jurisprudence Determined to an indifferent world John Stuart Mill came to his former teacher's assistance and published a very congratulatory review. In the course of that review Mill offered a pithy summary of Austin's project:

Jurisprudence ... does not take any direct cognizance of the goodness or badness of laws, nor undertakes to weigh the motives which lead to their establishment: it assumes their existence as a fact, and treats of their nature and properties, as a naturalist treats of any natural phenomenon. It furnishes an analytical exposition, not indeed of any particular system of existing laws, but of what is common to all or most systems of law.

[I]f we are to strip off from the arrangement and technical language of each system of law, whatever is purely accidental, and (as it may be termed) historical, having a reference solely to the peculiar history of the institutions of the particular people: if we were to take the remainder, and regularize and correct it according to its own general conception and spirit; we should bring the nomenclature and arrangement of all systems of law existing in any civilized society, to something very nearly identical. (Mill, 1984a: 55-56) ${ }^{1}$

Though neglected during his lifetime, Austin's work has gained in popularity after his death, so much so that when a century later H.L.A. Hart sought to revive interest in analytic jurisprudence it was to Austin's work that he turned as a basis for developing his own ideas. Though he subjected Austin's work to severe (and some say unfair) criticism, he seems to have adopted the

* Visiting Professor, Osgoode Hall Law School, York University (2010-11); Assistant Professor, University of Warwick School of Law. The essay will appear in translation to Spanish in a collection entitled Neutralidad y teor a del derecho: Memorias del I Congreso Filosof a y Derecho, and an in a similar collection in English.

${ }^{1}$ In a review of Austin's posthumously published Lectures on Jurisprudence, published some thirty years later, Mill (1984b: 173) described another characteristic of Austin's project: though he started with Roman law, his aims were to describe the general features of law. And "[b]y stripping off what belongs to the accidental or historical peculiarities of the given system [i.e., Roman law], the elements which are universal will be more surely and completely arrived at..." This is remarkably similar to the conception of jurisprudence found in Raz (2009a: 104-05). 
Austinian approach to the nature of the jurisprudential enterprise. And it is probably due to Hart's great influence that Austin's approach has remained dominant in (Anglophone) jurisprudential circles to this day. Indeed, what is most remarkable about the passages just quoted is how well they describe not just Austin's approach to jurisprudence, but what many people today take jurisprudence to be about.

Thus, Hart (1994: 239) characterized his effort in The Concept of Law as "general and descriptive"; Marmor (2006) defended the view that legal positivism is "descriptive and morally neutral"; Gardner (2001: 202) has argued that positivism is "normatively inert," and Green (2008: 1036) has criticized Fuller for failing to understand that Hart's project was not concerned with "giving advice" but rather with "trying to understand the nature of law." Other defenses of this view are abundant (e.g., Coleman 2007: 597-608; Kramer 1999: 129), and less directly the view can also be discerned in familiar contemporary ideas such as the distinction between the question "what is law (in general)?" and "what is the law (in a particular place)?," or in the claim that identification of the conditions of legal validity constitutes the most fundamental (Marmor 2007) or even the only proper (Wolheim 1954: 138-39) question of jurisprudence. It is probably best captured in the popular conception of "general" jurisprudence as concerned with the "concept," "essence," or "nature" of law.

I will call this view the Scientific Model of Jurisprudence (SMJ). I chose this name because the resemblance between jurisprudence understood in this way and a certain kind of (eighteenth century) science is quite remarkable. To get an idea of what I have in mind consider the following description of how Carl Linnaeus worked to identify species:

The flowers and fruits ... of a single species are to be described in detail; then from this description are to be removed all features found on comparison to vary from species to species; the result statement of features common to all species is the natural character of the genus. This was ... Linnaeus's original procedure, and doubtless always his aim though not always his achievement.... (Stearn 1957: 37).

Just like the eighteenth century botanical taxonomist, the legal philosopher on this model seeks to identify the central features of law and in this way to distinguish it from other phenomena. Though the similarly between the two enterprises is considerable, I must add a qualification or else the term SMJ and the analogy with natural science are prone to mislead: most contemporary legal philosophers (including most contemporary legal 
positivists) have adopted an anti-naturalistic or anti-positivist (in the sense this term is used in the philosophy of science) (Priel unpublished), so it may seem odd to suggest that legal philosophy is modeled after the sciences. To understand my claim, then, it would help to distinguish, as philosophers of science often do, between scientific aims, theories and methodologies (Laudan 1984: ch. 3). In devising jurisprudential theories proponents of SMJ often reject the methods of the natural sciences while endorsing (certain) of their aims.

The analogy with science helps us understand the appeal of SMJ: it looks like an innocuous activity with a respectable pedigree. It is uncontroversial that law is a phenomenon that exists in the world in some form, and it is also uncontroversial that it exists in different forms: there is criminal law and civil law; there is Roman law and Italian law; there is judge-made law and statutory law. Presumably there is something that unites all these together, and it is plausible to want to have an account of what that is. Nonetheless, in what follows I will argue that the philosophical project based on these plausible starting points is misguided. My strategy will be to spell out the assumptions underlying it and then argue that they are inconsistent.

\section{WHAT IS SMJ?}

$\mathrm{SMJ}$ rests on four assumptions.

1. The assumption of evaluative neutrality. The aim of jurisprudential theory is to provide an account of law that is morally neutral about the subject of her inquiry. The legal philosopher adopting SMJ may be a philosophical anarchist thinking that law can never be justified, or, less radically, that the laws of her country are too complex, rigid, unjust, inefficient (or simple, flexible, just, and efficient), but none of this is relevant to the question of the nature of law, what features something has to have in order to be law.

2. The assumption that legal philosophy is interested in the "deep" structure of law. In explaining the nature of law legal philosophers distinguish their work from both linguistics and sociology. On the one hand "the philosopher is not explaining how the word 'law' is used," (Hart 1994: 213; to the same effect: Gardner 2004: 168, 180; Raz 2009b: 29, 48; Shapiro, this volume); on the other she tries to avoid those accounts that tell us why or how the law developed in a particular time and place. Put differently, proponents of SMJ 
try to avoid both what might be called "superficial" accounts (as found in dictionary definitions) and parochial or contingent accounts. They are interested in what is necessarily true of law (Raz 2009a: 104-05; Dickson 2001: 17; Moore 2000: 306-08). This implies the legal philosopher should focus on identifying the conceptual connections that underpin the law: the connections that exist (if they exist) between law, obligation, authority, guidance, social order, and so on. In this the legal philosopher is like the botanist who tries to classify what a fish is (or, if you wish, the nature of fish-hood) not according to superficial features like shape or habitat, but on the basis of less visible, "deep" features based such as shared ancestors or genetic similarity. Probably for this reason much of the work of the leading proponents of SMJ is devoid of all historical or cultural context.

3. The assumption that different accounts are competing. Hart spoke of "the" concept of law, and much contemporary writing says that the primary question of legal philosophy is the identification of "the" nature of law. And it is because of this belief that many of the debates among legal philosophers-between legal positivists and natural lawyers, between legal positivists and Dworkinians, among different legal positivists of different stripes-only make sense if understood as competing accounts. To be sure, in recent years there have been several attempts to show that at least some of the competing views are reconcilable as they present different aspects of a complex phenomenon. But even these explanations (which are of course not accepted by everyone) do so from a standpoint of a theorist trying to identify the true nature of law, one that it is a major task of legal philosophers to describe in a manner consistent with the other assumptions discussed here.

4. The assumption of agreement on object of inquiry. According to this assumption in order for SMJ to be even possible we must have agreement over what counts as a sample of the object that we examine. If we are trying to discover what gold is, we must have some samples that are uncontroversially samples made of the substance we call (in English) "gold." There is no real disagreement about what gold is if it turns out that what one group of scientists calls "gold" refers to a sample the metal with atomic number $79(\mathrm{Au})$ and what another calls "gold" is a sample of iron pyrite ("fool's gold," $\mathrm{FeS}_{2}$ ). The same must be true of law. ${ }^{2}$ This assumption is not

${ }^{2}$ Sometimes a similarly sounding argument is used to argue for a certain substantive conclusion: the fact that two parties are engaged in what seems like a real argument shows that they are arguing about something real. In other words, 
frequently mentioned in jurisprudential debates, but only because it seems too obvious to state.

I hope that with the assumptions spelled out it is easier to see why I called this approach the scientific model. While conceptual legal theorists examine linguistic usage and intuitions as part of "conceptual analysis" of law-methods that no doubt are not central to modern science-the aims of jurisprudence quite closely resemble those of a scientist trying to discover, say, what water is. Such a scientist stands outside the examined phenomenon and tries to provide a description of its essential features while remaining neutral about whether it is a good thing or not. And just like what water is is not determined by its superficial features (liquidity at room temperature, transparency etc.) but by its "deep" molecular structure, legal philosophers work on the assumption that the answer to the question "What is law?" is to be determined in the same way. ${ }^{3}$ In the rest of the essay I will argue that, despite its superficial plausibility, SMJ is an indefensible research program.

\section{Assessing SMJ}

\section{The Challenges to SMJ}

My strategy against SMJ can be quickly stated: in the context of law the four assumptions specified above contradict each other. Why should we think that? We surely do not think that they are inconsistent in the case of the

genuine disagreement implies that skepticism about the domain is misguided. This has been a familiar argument made first by Dworkin, and then, ironically, leveled at Dworkin by his critics (Marmor 2001: 6). But this argument is mistaken. The point in the text is that for a disagreement to be genuine it has to be over the same thing; this does not imply that whenever an argument exists it follows that the disputants are talking about the same thing. Indeed, it is my point that proponents of SMJ fail to see that disagreements among legal philosophers may be the result of them talking about different things.

${ }^{3}$ Once again, things did not change much since Austin's day. Consider a similar analogy in another early review of Austin's work (Anonymous 1832: 107): "If we may be pardoned a simile, we would say that jurisprudence is to legislation what the science of chemistry is to the science of medicine; the one deals with necessary properties, the other with their application to a proposed end." 
natural sciences, so what makes law different? The gist of the argument is this: in order to explicate the nature of law the theorist must have an agreed object of inquiry, as required by the assumption of agreement on object of inquiry. The problem is how to determine what falls within this object of inquiry. As I see it a proponent of SMJ has to take one of three options: (a) to adopt the accepted usages of "law" by members of society, and then analyze the people's concept of law; (b) to attempt to provide an account of the origins of people's attitudes about law; or (c) to offer her own interpretation of those attitudes. A theorist adopting the first approach can only provide superficial definitions thus failing the assumption that the theorist is after the deep structure of law; if she adopts the second, she can provide deep analyses, but ones that are (by currently accepted standards) of little philosophical significance, and indefensible (even if true) because they lack adequate confirmation; and if the theorist adopts the third approach, she will have to adopt a particular understanding of the practice, which will require taking a stand on evaluative questions, thus violating the assumption of evaluative neutrality. In what follows I explore this trilemma more closely.

In order to provide an account of law there has to exist an agreement on what it is that it is to be explained. Without it we cannot know that when two theorists claim to disagree over the nature of law, their disagreement does not stem from the fact that they have different things in mind that they are describing. The problem is, however, that things don't usually come to the world clearly marked for what they are. Indeed, part of the motivation for SMJ seems to be the hope that jurisprudence could aid in the task of identifying law. But if we do not know in advance what it is that we are explaining, it may be that in deciding what counts as the object to be explained different theorists will already implicitly rely on different theoretical conceptions which will result in different views on what belongs to the object to be explained. These naturally will result in competing accounts, each true on its own terms but false on others. Each will be believed by its proponents to be a decisive argument against competing accounts, but could be dismissed as mistaken by proponents of other accounts. And at their core they will be circular (Priel 2010).

To avoid this problem legal theorists must agree on a neutral way of identifying their object of inquiry thus guaranteeing that whatever disagreements remain are not based on different objects of inquiry. Natural scientists avoid this problem by developing an agreed method for determining what counts as "the same thing." If trying to provide an account 
of the nature of an object with physical existence-be it gold or a human being - this can be by fixing the object of inquiry by ostention. Once certain samples have been agreed on, it is then possible to further develop a method for identifying classifying objects into categories. (This is not to deny that there may be some controversial marginal cases, but disagreements among scientists are usually not the result of disagreement over what belongs to the object to be explained.) This solution, however, is not available to legal philosophers: are the rules used by Nazi Germany belong to our object of inquiry or not? Or to take an issue that troubled many legal philosophers in the last two decades: are moral norms mentioned in legal sources part of the law? Legal philosophers tend to think this is a matter for them to decide according to theoretical arguments, but this is getting matters the wrong way around: what needs first to be established is whether these are cases of law which are part of the object to be explained. Any "descriptive" account that takes the object of inquiry as it is and seeks to explain it has to come afterwards.

Oddly, given the centrality of SMJ to contemporary jurisprudence, there is very little discussion on the matter. The implicit assumption in most jurisprudential work is that legal philosophers can rely on their knowledge as members of society and normal language users for a stock of examples of things that count as law, and that these are enough for identifying what law is in an uncontroversial manner prior to theorizing. Philosophers' appeal to intuitions at this stage may be thought a primitive method for gathering the relevant information for the theorist to develop his theories. Hart (1994: 3) was explicit on this point when he said that jurisprudential inquiry should begin with the attitudes of "educated people" about law. Counting himself among those Hart could then simply rely on his intuitive discriminations between law and non-law as the data on which to theorize.

There is an obvious problem with this approach: it assumes that all educated people have fairly similar attitudes on what counts as law, but this assumption may not be true. Indeed, as I will suggest below, there are good reasons for thinking that it is false. Further, even if it is true that the attitudes of educated people on what counts as law are similar, it is never explained why it is only their attitudes we should consider in fixing the object of inquiry, and not also those of, say, criminals who come in contact with the legal system, or, for that matter, those of uneducated people.

A more reliable method for discovering people's attitudes for the sake of fixing the object of inquiry would be to conduct surveys or obtain information 
on what people think belongs in the domain of law in some similar way. This will help guarantee that all theorists are offering competing accounts of the same thing and that the theoretical accounts offered by different theorists are not different because they describe different objects of inquiry. By themselves, however, such surveys would be of no philosophical significance. These surveys would, at best, discover some patterns of views, even perhaps a predominant view among people. Though such surveys might at first be resisted as the exact opposite of philosophical inquiry, such surveys might be thought a boon for the legal philosopher, because they would presumably not tell us much about what I called the deep structure of law. For a proponent of SMJ it is at this point that the theorist should come in and seek to identify the "folk theory" underlying people's attitudes as to what counts as law. ${ }^{4}$

Such an account looks at first as though it would fit the aim Raz and others have identified for jurisprudence: that of "helping people understand themselves" (Raz 1995: 237; Green 1996: 1717). Unfortunately, legal philosophers have not engaged in this kind of empirical inquiry for the sake of determining in a non-tendentious fashion what their object of inquiry is; and they do not seem particularly interested in the work of psychologists who have engaged in exactly such work (e.g., Tyler 1990).

Were philosophers to look into such work, all kinds of problems might emerge. For example, it is assumed by proponents of SMJ that there is a unique account of the nature of law, but it is not clear what a theorist would

${ }^{4}$ I think this is the case even in the case of natural kinds: even in those cases it is a societal "decision" to have a certain standard that may not be fully known to humans at the time they fix the reference and "baptize" it. We could have lived with a concept that covered every yellowish metal, instead of a concept that referred only to the metal with atomic number 79 and leaves it to scientists to tell us what its nature is.

The same is true of Moore's (2000) suggestion that law is a "functional" kind: whether he is right or not is ultimately a matter that cannot be determined by philosophical reflection, but rather by examining how the law is understood by the people engaging in it. This means that Moore can offer an account of $a$ certain functional kind that has the same attributes Moore gave to what he calls "law." Such an account would not be in any way undermined by the fact that most people's concept of law does not match Moore's account. On the other hand, this means that Moore's account has no descriptive significance (although it may still have prescriptively valuable). 
do if it turns out that people's attitudes turn out to be more or less evenly split between two or more views, or if it turns out that people's attitudes in one country are radically different from the attitudes of those people in another. In fact, we need not have such surveys to know that if surveys were to be conducted they are going to reveal different views. Among members of society some will be "legal positivists" believing that even immoral enactments are laws; there will also be some "natural lawyers" who will reject this view. (We know that this is so because the legal theorists themselves are members of society and so we know that we will find representation to both these positions and presumably to others as well.) Proponents of SMJ treat this as a debate on the best way to understand the object of inquiry, but they have no basis for treating it this way when the alternative-that it reflects different attitudes in what people take the object of inquiry to be-is also possible. To assume the former is not just to bias the argument in favor of the desired conclusion, it is to also to implicitly give SMJ a larger scope for inquiry than it should: for if it turns out that the question is one on which it is impossible to identify any clear view among members of society, this does not call for "conceptual" or "descriptive" debate. At best such a result would suggest that the concept of law is indeterminate on the matter. Any attempt to make matters more determinate by means of conceptual analysis (as opposed to a normative argument) will not illuminate the object of inquiry, but rather obscure it.

The typical way to deal with such differences about concepts in attitudes in time and place or between different individuals is the way sociologists, historians (and more recently, economists) go about it. They try to identify the factors that explain the divergence in attitudes, not to adjudicate between them as conceptually correct or incorrect. Such work is often of great interest and value for "helping people understand themselves," but it is not what counts as "philosophy," at least not as the term is currently understood and as currently practiced by proponents of SMJ.

How can the legal theorist avoid this predicament and provide a general account of the "nature" of law despite all the fundamental differences in attitudes about it? One way is to try and strip the account of all controversies and try and identify something that everyone could accept, in spite of, or before, all the differences. If properly done, such a definition may be able to provide us with an account that does not violate the assumption of agreement over object of inquiry, for it would be based on people's attitudes that would set the boundaries of the object of inquiry. But the cost of 
maintaining the assumption of agreement on object of inquiry and (perhaps) also the assumption of evaluative neutrality would be an account that would not satisfy the assumption that the aim of the inquiry is revealing the deep structure of law. The kind of account that most resembles this solution to the problem is what we find in dictionaries.

The way to get around this problem is for the theorist to take people's attitudes as to what counts as law and then provide the kind of account that would satisfy the assumption of deep analysis. But I will argue there is no way of doing this without violating the assumption of evaluative neutrality. There are at least two reasons why. First, in order to explain the "nature" of law in this way the theorist will have to account for many different attitudes among members of society about the nature of law. The theorist will have to decide among those different views, for example by considering some to be more central or representative than those of others. If in doing this the theorist bases her judgment on a certain implicit view of what law is, then her account is bound to be fallacious for assuming the conclusion it reaches. To avoid this, the theorist will have to base her account not on a view on what law is, but on some normative judgments of the sort of goals law is to achieve, its role in society, its relationship with other institutions and so on. But these are, of course, evaluative judgments, and will thus result in violation of the assumption of evaluative neutrality.

Second, even if there are no differences among members of society about the nature of law, in order for the theorist to turn the "raw materials" of people's attitudes into a theory, he will have to resort to evaluative judgments. The move from data to theory is the stage at which the theorist provides "a map exhibiting clearly the relationships dimly felt to exist between the law they know and other things" (Hart 1994: 14). There are, however, many possible ways of turning the data, even after it has been purged off contingencies, into theory. Consider the following example: Hart's account of the nature of law, the union of primary and secondary rules, ignored the distinction between criminal law and tort law and more generally between criminal law and civil law, distinctions that lawyers (and often non-lawyers) treat as fundamental. Why did he do that? This question cannot be answered, of course, by saying that since both tort law and criminal law contain rules directed at the public, they are both made up of primary rules and they belong together. Not only is this statement not entirely accurate (Dan-Cohen 1984), it begs the question why it is that the identity of the rule-subjects should be the basis for distinguishing between 
types of rules. And then there are rules that do not sit comfortably in either category. Are what Calabresi and Melamed (1972) called "liability rules," the likes of which are easily found in many legal systems, primary or secondary rules?

Hart's presumably thought that there is something illuminating in his distinction between primary and secondary rules, but not (for a general account of law) between criminal law and tort law, which is why his key to the science of jurisprudence highlighted the former but ignored the latter. But so exactly was the case with other theorists who have sought to eliminate the distinction Hart thought important between primary and secondary rules. They thought that we will gain further illumination by showing that secondary rules can be explained as a part of primary rules. Still others thought that all rules can be illuminated by explaining them in terms of behavior, exactly because they removed from the explanation the obscure and unverifiable internal workings of the human mind. Hart, by contrast, thought such approaches were mistaken because in their search for "reduction" they resulted in "distortion" (Hart 1994: 38-42, 89-91). The problem is then is how to distinguish between those cases in which reduction is illuminating and those in which it is distorting at the stage of inquiry in which the theorist moves beyond the attitudes that make up folk law and thus it is unlikely that we could turn to lay people for help on this matter.

All this does not show that Hart's account was mistaken. But it does show that just like those alternative accounts he criticized, his account contained a degree of reduction, unification, analysis and synthesis of what he found in his object of inquiry. It is just that what he thought was illuminating was different from what, say, Bentham or Kelsen did. There is an element of choice here (as Hart essentially admits at in Hart 1994: 213), and so the question is how to decide between competing accounts. We might say "to each his own," and leave it at that, but this would imply that Hart's criticisms of other theories (criticisms nowadays widely thought to be correct) are mistaken for presupposing a right answer where there is none. Or we might say that at this point there is nothing more than intuition to tell us which account is correct.

In their different ways, however, both suggestions lead to the conclusion that there is little point in jurisprudential debate. We have seen before one use for intuitions. In that use intuitions were seen as an means for fixing the object of inquiry by means of introspection instead of surveys. 
By contrast, in the present context intuitions are used to decide between competing theories. The result would be (or rather, the result has been) that each theorist would develop the account that she finds intuitively illuminating, but there would be no way, even in principle, of telling who is right. Thus, this approach leads to violating the assumption that the theories are competing.

To avoid this outcome, legal philosophers will have to examine what it is that is behind their intuitions. I suppose some of those intuitions are going to be about what counts as a good explanation in general. But in part would counts as good explanation will depend on what is being explained as well as certain evaluative judgments about what is significant about it. For example the distinction between criminal law and civil law reflects attitudes on the right relation between different individuals and the relationship between individuals and state. (Libertarians, for example, may wish to expand the domain of private law "restorative justice" at the expense of the retributive justice of public criminal law: Barnett 1977.) Similarly, Hart's statement that contracts are "a relatively minor legal institution" (Hart: 1968: 10), a statement which perhaps explains why contracts do not figure prominently in his theory of law, would be challenged by others who see contracts as the paradigm of individual autonomy and the only theoretical foundation for societal coercion. Deciding to remove these elements from one's account of the nature of law thus cannot be neutral. What we see, then, that once the intuitions on what to include and what to exclude from the account are brought to light, they violate the assumption of evaluative neutrality.

If my argument is correct, it should be by now clear that SMJ is indefensible. Let me summarize my reasons for thinking that: I began by articulating the sort of requirements necessary for providing a uniquely philosophical account of the nature of law in general, as distinct from sociological or historical accounts of the development of law in a particular place. I proposed three ways of articulating this idea, but all three ended in failure. The first interpretation of SMJ maintained the requirement of evaluative neutrality but could only lead to something like a dictionary definition, the kind of account that legal philosophers themselves have said they are not pursuing. The second interpretation avoided the problem of superficiality but only at the expense of providing an account that was historical or sociological (and thus necessarily particular) and so clearly different from what one finds in the leading examples of SMJ. The third interpretation avoided both problems, but it did so by offering an 
interpretation of legal practice which violated the assumption of evaluative neutrality.

\section{Possible Objections}

As something like the third interpretation is what I think legal philosophers have in mind as what they are engaged in SMJ, it should not come as a surprise that they have focused their efforts on ways of averting its problematic conclusions. Here I can only consider the two (related) ways that have found most support among defenders of SMJ.

\section{Judgments of Importance}

Following Raz's lead (1995: 209, 235) many proponents of this view have conceded that any attempt at capturing the nature of law must be based on evaluative considerations of importance (Coleman 2001: 177-78; Krmaer 2004: 158, 236; Green 1987: 15; Waluchow 1994: 19-29; Dickson 2001; Hart 1987: 36; Marmor 2001: 156). We are told, however, that these are different from moral evaluations. On this view the assumption of evaluative neutrality is somewhat weakened: a proponent of SMJ (just like any scientist) must rely on certain values, but those are not moral values, only judgments of importance.

Though popular this position is usually asserted rather than defended. Few legal theorists have considered seriously the way in which judgments of importance are to figure in their account and whether such judgments can be separated from other evaluative judgments. It is often assumed that the only role evaluative judgments play is in narrowing down the number of truths the theorist has found out. Even on these grounds this answer is unsatisfactory. Judgments of importance are subjective, and as such incapable of generating conclusions that can be the basis of rational disagreement. If this is the case, it would suggest that much of the disagreement among legal philosophers cannot be resolved, rendering most jurisprudential debates among proponents of SMJ pointless (Priel 2010).

We might not have been troubled by this fact had competing accounts been simply considered different and complimentary ways of accounting for the same phenomenon. But this is not what jurisprudential debates look like: they are usually presented as challenges to competing views. In other words, to present all competing account as the result of different judgments of importance would solve one problem but will do so at the cost of casting 
doubt on the very idea of SMJ. We would have to conclude that all legal theories are merely possible interpretations of the object of inquiry. Apart, perhaps, from errors of contradiction, any account would be immune from criticism as it would be considered illuminating in the eyes of its proponents.

This means that in order to make current debates intelligible there must be some way of assessing judgments of importance. But what is it that makes something important about law? Answering this question is particularly difficult for those proponents of SMJ who deny that law has any general purpose or function (e.g., Hart 1994: 243; Raz 2009b: 374-75). Even then, however, it is possible to say that given certain empirical observations about what laws are used for (proscribe and prescribe behavior, create obligations and powers, express and communicate on moral matters, affect the social meanings of certain activities) it is plausible that at least some of the things that are important about law have to do with evaluative concepts like autonomy, responsibility, liberty, authority, community, and agency. Making judgments of importance would inevitably embroil the theorist with questions about these concepts. (I ignore here the fact that it may be that those values may change from time to time and place to place, even though this is, obviously, an additional serious problem for SMJ.)

At first this sounds like good news for the proponent of SMJ. If there is an objective account of values, then judgments of importance based upon them will presumably be objective as well, and if this is true we can thus avoid the challenge that judgments of importance cannot be the basis for debate. But even if some true account of objective values exists, what those happen to be is a matter of great controversy and would effectively require abandoning the assumption of evaluative neutrality. Hence, resorting to the objectivity of values as a way of solving conflicts about judgments as to what is important about law is unlikely to prove a very promising strategy. Judgments of importance then are either subjective, in which case the assumption that the debates are conflicting will have to be dropped; or they are objective, in which case in all likelihood they depend on certain value judgments, which require rejecting the assumption of evaluative neutrality. ${ }^{5}$

${ }^{5}$ Whether there is a way around this problem is discussed in the next subsection, but even if this answer is successful, the help it provides is limited. The role assigned to judgments of importance in this view is that of distinguishing important or interesting truths from unimportant and uninteresting ones. Recall, however, that one of the challenges to SMJ as currently practiced is that evaluative 


\section{Description of an Evaluation}

The second way for avoiding the conclusions of the last section is the suggestion that it is possible to describe an evaluative stance without endorsing it. It is epitomized in the words of Hart (1994: 244) that "description remains a description even when what it describes is an evaluation," and it has been supported by many proponents of SMJ.

This claim is usually made independently of the argument just discussed about judgments of importance, but I think it is better understood as part of a single argument. (I will address it in this way, but my challenge to it general and as such applies to it whether made as part of another argument, or independently.) When taken together, this idea seems to provide a way out of the dilemma posed in the end of the last subsection: ${ }^{6}$ it might be thought that it is possible to describe values without endorsing them may seem to be most important: this way we may base our account of objective values of importance seemingly without violating the assumption of evaluative neutrality as the theorist would not need to make judgments of importance, only describe them.

This is by no means an uncontroversial view (McDowell 1998), but I will ignore this point here. The main difficulty with it is that even if true it does not help the proponent of SMJ, for judgments of value are made here not at the stage of the gathering of data; they are made at the stage of turning the data into theory. At this stage the theorist goes beyond existing attitudes trying to articulate what she considers underlies them. For Hart, for example, this was guidance of conduct; for Dworkin, by contrast, it is encouraging political participation and the inculcation of a certain rightbased view among citizens towards each other. Both thought this is something that can be found in the practice, but for both this required an elaboration of the relation between individuals and the state, and relations among individuals. These were based on certain (different) judgments about

judgments are required for the sake of specifying what belongs in the object of inquiry. Whatever one may think of the claim that non-moral judgments of importance are sufficient for narrowing down the results of our inquiry, they are incapable of specifying the object of inquiry.

${ }^{6}$ Possibly another way out is Platonism about values. But this position is not only implausible, it would also require proponents of SMJ to add to their theory such heavy metaphysical baggage that the original appeal SMJ may have had would be completely lost. 
personhood and morality. In Hart's case, for example, the Humean conception of morality he endorsed was not merely a description of values, it was exactly in line with the relatively skeptical views he held about moral value, which are of course very different from Dworkin's, and are no doubt very different from those of other people. In relying on them for the sake of his theory Hart was not merely describing the evaluations of others, he was making his own evaluative judgments. And had Hart succeeded in accurately describing certain values, those would have been the values of a particular time and place, and the account of the nature of law dependent upon them correspondingly relative.

\section{Does the Argument Prove Too Much?}

If all this is true, does it not show that no description of any social practice or institution is possible? For what I said of law is arguably true of other social practices as well. And is it not absurd to suggest that we cannot give a descriptive account of notions like money, marriage, or property?

If that were the case, it would suggest that somewhere along the way something has gone wrong with the argument. But this is not the case. It is possible, of course, to describe social practices; my challenge to SMJ is based on the way it is purported to be done. There are at least four different ways in which social practices may be described. The first is for the theorist to provide her own definition. As Humpty Dumpty has told us one may give words any meaning one wishes; but for the sake of fruitful conversation one would better define one's words in a manner that bears some similarity to the way others use the term. It is clear, however, that here-so long as the theorist is clear about her definitions-it is of little concern if her definitions depart from prevalent views. In any case, such definitions are only provided for the sake of further inquiry, not as an end in themselves. This, then, is not what proponents of SMJ are after.

A second way of describing social practices, already mentioned, is by providing the kind of descriptions found in dictionaries: here the aim is to capture some superficial prevalent linguistic usage. Dictionary definitions are not always free from evaluative judgments, but they try to avoid them exactly by providing the kind of superficial descriptions that proponents of SMJ have insisted they are not concerned to provide.

A third and more interesting way of describing social practices is by analyzing the different attitudes of individuals as found in society. Such 
analyses usually aim to show the ways in which such attitudes differ according to factors like age, gender, wealth, education, ethnicity, nationality, and so on, and they do so for the sake of showing some kind of causal connection, or at least correlation, between some such factors and the resulting practice. Such an account might reveal, for example, that in a certain state the most people are "legal positivists" in thinking that legality is not determined by morality whereas in another the majority thinks differently and will try to trace this difference to, for example, the different political histories of the two states. Needless to say, this is quite different from the "general and descriptive" approach of Hart and other proponents of SMJ.

Finally, there is the interpretive approach which seeks to provide an interpretation of a practice in light of certain values that are argued to underlie it. There are different ways of specifying this approach, but on any formulation this approach depends quite explicitly on making certain evaluative judgments about the practice (Taylor 1985; Geertz 1973). The theorist on this view must take the "data" and interpret them to show what he thinks are the values the practice best serves. In the context of law, such interpretations will inevitably depend on moral values. It is hardly worth noting here that in the area of jurisprudence the best known proponent of this approach in recent decades, Ronald Dworkin, has also been a longstanding opponent of SMJ. ${ }^{7}$

All these are viable methods of explaining social practices in general and law in particular, and it is not difficult to name successful examples of each. To give just one example of an attempt to describe a social institution, Zelizer's (1994) work on the social meaning of money, which blends elements of the third and fourth approaches, may well contribute to our selfunderstanding, but it is very different from the work of analytic legal philosophers. In fact, outside jurisprudence it is very difficult to find other social practices subject to anything resembling SMJ.

${ }^{7}$ This essay is not concerned with defending Dworkin's views, so I will not consider at length the question whether his specific views avoid the criticism of SMJ. I will only note that I think his reliance on the "pre-interpretive stage" (Dworkin 1986: 64-66), which many positivists have thought to be a fatal concession to their theory, does not implicate Dworkin's theory with SMJ. For his approach it is enough that the pre-interpretive stage captures the superficial understandings of law, which the theorist then interprets. 


\section{Concluding Remarks}

There is an interesting historical question as to why jurisprudence has taken this turn towards SMJ. In part the answer has to do with the dominance of legal positivism among legal philosophers. Though I did not discuss this matter here, there is no doubt that most proponents of SMJ are legal positivists. But when looking at figures like Hobbes or Bentham, thinkers who in various ways are harbingers of contemporary legal positivism, it is clear that their legal positivism had nothing to do with SMJ. Here, I suspect an important part of the story has to do with the immense influence Hart has had on Anglo-American jurisprudence. Hart felt more secure in the Austinian version of legal positivism than in Bentham's more openly political version, because unlike Bentham he was unsure about the foundations of morality and of his ability to engage in the kind of Benthamite project in which law is only part of a grander scheme. Making legal philosophy "descriptive" by separating it from political philosophy may have seemed to him, consciously or unconsciously, like an attractive way of doing philosophy without having to tackle these broader concerns. Hart's lead was then followed by others, even those who did not share his metaethical doubts.

Apart from Hart it may be that the other main theorist to entrench SMJ may have been, ironically, its leading contemporary detractor. As part of his critique of legal positivism Dworkin has made the claim, implicitly at first and explicitly in more recent writings, that there is no clear distinction between describing individual legal propositions and making a normative claim as to their correctness. This was part of a very thoroughgoing and not always carefully articulated rejection of what Dworkin called Archimedeanism (Dworkion 1996). In their eagerness to reject a position that seems to lack in precision, legal positivists may have reacted by insisting on the significance of SMJ as the foundation of jurisprudential inquiry. This may have been an overreaction: what was missed was a more nuanced position, namely that any philosophically significant account of law would depend on making some moral and political judgments as to the place of law in society and alongside other regulatory institutions while rejecting Dworkin's stronger claims about individual propositions of law. 


\section{WORKS CITED}

ANONYMOUS, 1832: Review of John Austin, The Province of Jurisprudence Determined. The Jurist , 3: 105-22.

BARNETT, R.E., 1977: "Restitution: A New Paradigm of Criminal Justice" Ethics 87: 279-301.

CALABRESI, G., \& A.D. MELAMED, 1972: "Property Rules, Liability Rules, and Inalienability: One View of the Cathedral" Harvard Law Review, 85: 1089-1128.

COLEMAN, J.L., 2007: "Beyond the Separability Thesis: Moral Semantics and the Methodology of Jurisprudence" Oxford Journal of Legal Studies, 27: 581-608.

COLEMAN, J.L., 2001: The Practice of Principle: In Defence of a Pragamatist Approach to Legal Theory. Oxford: Oxford University Press.

DAN-COHEN, M., 1984: "Decision Rules and Conduct Rules: On Acoustic Separation in Criminal Law" Harvard Law Review 97: 625-677.

DICKSON, J., 2001: Evaluation and Legal Theory. Oxford: Hart Publishing. DWORKIN, R., 1986: Law's Empire. Cambridge: Harvard University Press. DWORKIN, R., 1996: "Objectiveity and Truth: You'd Better Believe It" Philosophy and Public Affairs 25: 87-139.

GARDNER, J., 2001: "Legal Positivism: 5 Myths" American Journal of Jurisprudence, 46: 199-225.

GARDNER, J., 2004: “The Legality of Law" Ratio Juris, 17: 168-81.

GEERTZ, C., 1973: The Interpretation of Cultures: Selected Essays. New York: Basic Books.

GREEN, L., 2008: "Positivism and the Inseparability of Law and Morals" New York University Law Review, 83: 1035-1058.

GREEN, L., 1987: "The Political Content of Legal Theory" Philosophy of the Social Science, 17: 1-17.

HART, H.L.A., 1968: Punishment and Responsibility: Essays in the Philosophy of Law. Oxford: Clarendon Press.

HART, H.L.A., 1987: "Comment" in R. Gavison (ed.), Issues in Contemporary Legal Philosophy: The Influence of H.L.A. Hart, 35-39. Oxford: Clarendon Press.

HART, H.L.A., 1994: The Concept of Law (2nd ed.). Oxford: Clarendon Press.

KRAMER, M.H., 1999: In Defense of Legal Positivism: Law without Trimmings. Oxford: Oxford University Press. 
KRAMER, M.H., 2004: Where Law and Morality Meet. Oxford: Oxford University Press.

LAUDAN, L., 1984: Science and Values: The Aims of Science and Their Role in Scientific Debate. Berkeley: University of California Press.

MARMOR, A., 2001: Positive Law and Objective Values. Oxford: Oxford University Press.

MARMOR, A., 2006: Legal Positivism: Still Descriptive and Morally Neutral. Oxford Journal of Legal Studies, 26: 683-704.

MARMOR, A., 2007: The Nature of Law. Retrieved from Stanford Encyclopedia of Philosophy: http://plato.stanford.edu/entries/lawphilnature.

McDOWELL, J., 1998: Mind, Value, and Reality. Cambridge: Harvard University Press.

MILL, J.S., 1984a: "Austin's Lectures on Jurisprudence" in The Collected Works of John Stuart Mill (Vol. 21). Toronto: University of Toronto Press.

MILL, J.S., 1984b: "Austin on Jurisprudence" in The Colected Works of John Stuart Mill (Vol. 21). Toronto: University of Toronto Press.

MOORE, M.S., 2000: Educating Oneself in Public: Critical Essays in Jurisprudence. Oxford: Oxford University Press.

PRIEL, D., 2010: "Description and Evaluation in Jurisprudence" Law and Philosophy 29.

PRIEL, D., unpublished: "Jurisprudence between Science and the Humanities" Retrieved from http://ssrn.com/abstract $=1566858$.

RAZ, J., 1995: Ethics in the Public Domain: Essays on the Morality of Law and Politics (Rev. ed.). Oxford: Clarendon Press.

RAZ, J., 2009a: The Authority of Law (2nd ed.). Oxford: Oxford University Press.

RAZ, J., 2009b: Between Authority and Interpretation. Oxford: Oxford University Press.

STEARN, W.T., 1957: "An Introduction to the Species Plantarum and Cognate Botanical Works of Carl Linnaeus" in C. Linnaeus, Species Plantarum: A Fascimile of the First Edition 1753 (Vol. 1, pp. 1-176). London: Ray Society.

TAYLOR, C., 1985: Philosophy and the Human Sciences. Cambridge: Cambridge University Press.

TYLER, T.R., 1990: Why People Obey the Law. Princeton: Princeton University Press. 
WALUCHOW, W., 1994: Inclusive Legal Positivism. Oxford: Clarendon Press.

WOLLHEIM, R., 1954: “The Nature of Law" Political Studies , 2: 128-41.

ZELIZER, V., 1994: The Social Meaning of Money: Pin Money, Paychecks, Poor Relief and Other Currencies. New York: Basic Books. 